15 King S, Ricard N, Rochon V, Steiger H, Nelis S. Determinants of expressed emotion in mothers of schizophrenia patients. Psychiatry Res 2003; 117: 211-22.

16 Barrowclough C, Parle M. Appraisal, psychological adjustment and expressed emotion in relatives of patients suffering from schizophrenia. Br J Psychiatry 1997; 171: 26-30.

17 Hooley JM. Expressed emotion and locus of control. J NerV Ment Dis 1998; 186 374-8

18 McFarlane WR. Family interventions for schizophrenia and the psychoses: a review. Fam Process 2016; 55: 460-82.

19 Gurak K, Weisman de Mamani A. Caregiver expressed emotion and psychiatric symptoms in African-Americans with schizophrenia: an attempt to understand the paradoxical relationship. Fam Process 2017; 56: 476-86.

20 López SR, Ramírez García Jl, Ullman JB, Kopelowicz A, Jenkins J, Nicholas J, et al. Cultural variability in the manifestation of expressed emotion. Fam Process 2009: 48: 179-94.

21 Kopelowicz A, Zarate R, Wallace CJ, Liberman RP, Lopez SR, Mintz J. Using the theory of planned behavior to improve treatment adherence in Mexican Americans with schizophrenia. J Consult Clin Psychol 2015; 83: 985-93.

22 Medina-Pradas C, Navarro JB, Pousa E, Montero Ml, Obiols JE. Expressed and perceived criticism, family warmth, and symptoms in schizophrenia. Span J Psychol 2013; 16: E45.

23 Santesteban-Echarri O, Ramos-Olazagasti MA, Eisenberg RE, Wei C, Bird HR, Canino G. Parental warmth and psychiatric disorders among Puerto
Rican children in two different socio cultural contexts. J Psychiatr Res 2017; 87: 30-6.

24 Ruby MB, Falk CF, Heine SJ, Villa C, Silberstein O. Not all collectivisms are equal: opposing preferences for ideal affect between East Asians and Mexicans. Emotion 2012; 12: 1206-9.

25 Lim N. Cultural differences in emotion: differences in emotional arousal level between the East and the West. Integr Med Res 2016; 5: 105-9.

26 Resnicow K, Baranowski T, Ahluwalia JS, Braithwaite RL. Cultural sensitivity in public health: defined and demystified. Ethn Dis 1999; 9: 10-21.

27 Wang-Schweig M, Kviz FJ, Altfeld SJ, Miller AM, Miller BM. Building a conceptual framework to culturally adapt health promotion and prevention programs at the deep structural level. Health Promot Pract 2014; 15: 575-84.

28 Wearden AJ, Tarrier N, Barrowclough C, Zastowny TR, Rahill AA. A review of expressed emotion research in health care. Clin Psychol Rev 2000; 20 633-66.

29 Lister Z, Wilson C, Fox C, Herring RP, Simpson C, Smith L, Edwards L. Partner expressed emotion and diabetes management among spouses living with Type 2 diabetes. Fam Syst Health 2016; 34: 424-8.

30 Rylander AJ, McKie S, Elliott R, Deakin JF, Tarrier N. A functional magnetic resonance imaging paradigm of expressed emotion in schizophrenia. J. NerV Ment Dis 2011; 199: 25-9.

31 Palmer BW, Martin AS, Depp CA, Glorioso DK, Jeste DV. Wellness within illness: happiness in schizophrenia. Schizophr Res 2014; 159: 151-6.

\title{
Reflection
}

\section{Light at the end of the tunnel: a front-line clinician's personal narrative on COVID-19 and mental illness}

\author{
Venkat Ramesh iD
}

I have suffered from generalised anxiety disorder with depression ('anxious depression') and obsessive-compulsive traits, first diagnosed at age 18 in my first medical school year. I have been on four courses of selective serotonin reuptake inhibitor antidepressants, sometimes along with clonazepam and buspirone: sertraline in 2006, fluvoxamine in 2009, escitalopram in 20122013 and 2017-2018. I have been off psychiatric medication since March 2018.

I am a physician and an adult infectious diseases specialist by training - a training completed in April 2020, just as the COVID-19 pandemic began to hit.

For people like me with anxiety issues, COVID-19 has made an already challenging condition worse. The hardest part of working in the front line, treating patients with COVID-19, was the constant daily angst and dread of being infected with a disease with an unpredictable clinical course and no definite cure.

I survived 2020 without being infected. In late January 2021, three days before my scheduled vaccination, I tested positive for SARS-COV-2.

The initial symptoms were mild but distressing, with low-grade fever, malaise and a throbbing headache. The most unpleasant were palpitations and what I can now recognise as 'brain fog', being unable to focus or concentrate. Unfortunately, all this triggered a massive anxiety episode. I had trouble sleeping because of tachycardia and palpitations. Worrisome, intrusive thoughts filled my mind: What if I die? What if I require admission into the intensive therapy unit (ITU)? Having treated hundreds of patients, I had envisioned for myself five worsening clinical states: the need for admission into the hospital, need for supplemental oxygen, admission to the ITU, invasive mechanical ventilation and death. I kept pacing around in anxious tension, and a relapse seemed imminent.

However, then I realised I was only repeating the same old cycle. I decided then that, come what may, I would not let fear dominate me. I had academic assignments to complete and would focus on them. If my mind wandered and my heart pounded, and I felt anxious, so be it. I reread portions of Paul David's books At Last A Life and At Last A Life and Beyond, two books that have helped me immensely. I have also found valuable insights in the book You Are Not Your Brain, by Drs Jeffrey M. Schwartz and Rebecca Gladding. I had previously found success with mindfulness and acceptance, and cognitive-behavioural therapy, and I knew this episode was no exception.

I gradually improved, made a complete and uneventful recovery, and took the first dose of the vaccine two weeks later.

The COVID-19 pandemic is an opportunity to bring into the limelight the importance of mental health and well-being. We need to be strong advocates for breaking barriers and increasing access to mental health resources.

(c) The Author(s), 2021. Published by Cambridge University Press on behalf of the Royal College of Psychiatrists 